Volume 2, No. 22020

P-ISSN: 2655-5166

E-ISSN: 2715-2103

Homepage : http://journal.iaimsinjai.ac.id/indeks.php/retorika

\title{
Citizen Journalism (Jurnalisme Warga): Dari Fakta Berita dan Profesionalitas
}

\author{
R. Firdaus Wahyudi ${ }^{1}$ \\ 1 cheyudi@yahoo.co.id
}

\begin{abstract}
Abstrak
Citizen journalisme atau jurnalisme warga dimana kehadirannya merupaka suatu respon terhadap teknologi komunikasi berbasis internet atau digital yang sering juga dikenal dengan media baru. Dengan berbagai plaformnya, media baru tersebut memberi ruang setiap individu dalam melakukan aktifitas yang selama ini senantiasa dilakukan oleh wartawan media konvensional atau jurnalisme profesional. Citizen journalism merupakan aktivitas individual terkait pemerolehan, pengelolahan dan penyebaran peristiwa, fakta atau kejadian berupa berita yang disampaikan melalui media sosial. Berita atau informasi merupakan suatu perwujudan dari pemerosesan suatu peristiwa, data atau fakta yang senantiasa melibatkan unsur-unsur nilai perspektif dan kepentingan namun tentunya mesti tidak mengabaikan standar pembuatan berita yang profesional. Disamping itu citizen journalism mesti senantiasa dituntut bekerja dalam koridor profesionalitas yang tercermin dalam kode etik jurnalistik yang berlaku. Penelitian ini merupakan penelitian kualitatif melalui studi pustaka terkait dengan citizen journalism (jurnalisme warga). Adapun hasil penelitian ini adalah bahwa citizen journalisme merupakan aktifitas warga yang terlibat dalam dunia jurnalistik atau penyampain berita, kerja citizen journalisme dituntut untuk sesuai dengan standar pembuatan berita dan kerja jurnalisme profesional, walaupun demikian secara payung hukum, citizen journalisme tidak memiliki payung hukum sebagaimana jurnalisme profesionalisme.
\end{abstract}

Kata kunci. Citizen Journalism. Fakta Berita. profesionalisme

\section{Pendahuluan}

Semenjak mesin cetak ditemukan oleh Johann Gutenberg dari Mainz, maka konstelasi gerak perkembangangan umat manusia terutama dalam bidang komunikasi mengalami perubahan yang signifikan. Menurut Asa Briggs \& Peter Bruke $^{1}$ bahwa praktek percetakan tersebar luas di seluruh eropa, dimana pada tahun

\footnotetext{
${ }^{1}$ Asa Briggs \& Peter Burke. Sejarah sosial Media dari Gutenberg sampai Internet. Penj. A. Rahman zainuddin (pustaka Obor, Jakarta. 2006)
} 
Volume 2, No. 22020

P-ISSN: 2655-5166

E-ISSN: 2715-2103

Homepage : http://journal.iaimsinjai.ac.id/indeks.php/retorika

1500 lebih dari 250 percetakan terbit. Demikian pula pada awal 1920an, hadirnya teknologi televise mengubah pula wajah social dari masyarakat. Meskipun eksistensi percetakan (media cetak) tidak tergoyahkan, keberadaan televisi dengan menyuguhkan informasi dalam skala internasional memungkinkan interaksi yang lebih massif dan pengetahuan lebih luas pada diri masyarakat. Masyarakat dunia semakin menyatu atau apa yang dikatakan McLuhan sebagai "global village". Perkembangan teknologi tidak hanya berhenti pada teknologi visual saja , salah satu momen yang luar biasa adalah ditemukannya computer pada awal 1960-an dan pada tahun 1990 an internet kemudian dikembangkan. Temuan internet menurut Bungin tidak hanya saja mampu mentransmisikan berbagai informasi, namun juga telah mampu menciptakan dunia baru dalam realitas kehidupan manusi, yaitu sebuah realitas materialist yang tercipta dalam dunia maya. Realitas itu adalah apa yang dikatakan oleh Wilhem sebagai masyarakat virtual (virtual society) ${ }^{2}$.

Dari sudut pandang masyarakat, keberadaan teknologi komunikasi media cetak, eloktronik dsb, menggeser tradisi lisan atau transmisi suatu peristiwa melalui mulut-kemulut. Koran, radio, televisi membuat masyarakat dengan mudah mengetahui segala jenis informasi atau berita yang terjadi disekitarnya atau bahkan diseluruh dunia. Kemudahan informasi yang didapatkan meningkatkan kapaisatas ilmu dan pemahaman manusia sehingga berakibat pada peningkatan kualitas hidup manusia. Gejala melek media sebenarnya berkorelasi erat dengan perkembangan teknologi komunikasi tersebut. Tingkat komsumsi terhadap berita-berita media adalah perwujudan bahwa manusia senantiasa yang didorong oleh rasa ingin tahu. Dalam ranah komunikasi, mengemukakan pendapat, menyampaikan berita atau tangapan yang kemudian di mediasi oleh perusahaan cetak, melalui kolom pembaca, opini atau melalui Televisi seperti suara pembaca hingga suara anda misalnya (Metro TV) adalah bentuk perwujudan dari dimensi ini. Namun bentuk partisipasi ini sifatnya terbatas dikarenakan seperti: pembatasan kolom atau isu-isu yang ingin

\footnotetext{
${ }^{2}$ Prof. dr. H. Muh. Burhan Bungin. Sosiologi Komunikasi Cet 7 (PrenadaMedia Group. Jakarta 2014)
} 
Volume 2, No. 22020

P-ISSN: 2655-5166

E-ISSN: 2715-2103

Homepage : http://journal.iaimsinjai.ac.id/indeks.php/retorika

dipublikasikan serta sifat selektif dari struktur pengelolah media tersebut. Masyarakat yang ingin berpartisipasi secara bebas, tanpa kendala-kendala sebagaimana disebutkan sebelumnya bisa sebenarnya mendirikan media cetak itu sendiri. Namun hal ini tidaklah mudah karena butuh modal yang tinggi, struktur organisasi dan sebagainya. Sehingga tidak memungkinkan secara individual.

Keberadaan Komputer serta internet yang begitu massif dengan fitur yang canggih memungkinkan terjadi pengambil alihan peran-peran dari media konvesional (seperti Koran,televisi, radio dsb) atau sebagaimana dikatakan oleh Barran \& Davis ${ }^{3}$ bahwa setiap kemunculan teknologi media baru mengganggu stabilitas media yang memaksa dilakukannya resturkturasi dalam sekala luas dan terjadi peubahan yang cepat "Functional displacement". Keberadaan internet yang melahirkan masyarakat virtual memungkin individu melakukan aktualisasi diri, terlebih-lebih ketika meningkatnya jumlah pengguna intenet yang diakibatkan semakin murahnya haraga smartphone atau gadget hingga computer atau laptop serta perluasan area Hot-spot atau wi-fi (langganan internet semakin murah) memungkinkan lintas informasi yang semakin intens yang melibatkan individu yang tidak terikat dengan struktur perusahaan media. Keberadaan blog atau situs pribadi serta media sosial (Facebook, Intagram, Twitter dan sebaginya) yang memuat opini atau berita tanpa harus melelui proses kerja jurnalistik yang formal atau struktur komunikasi yang formal, kaku dan jelimet adalah perwujudan apa yang dikenal sebagai fenomena jurnalisme warga (citizen journalism). Dari perspektif pengelolah media cetak (Koran) atau visual Televisi dan audio dimana semakin goyahkan dengan keberadaan internet dan blogger (jurnalisme warga) hingga media sosial, kemudian melakukan modifikasi dengan mencoba menyisipkan kolom, segmennya yang melibatkan warga (atau produk individu) seperti metro menyajikan "video anda", Koran "kolom anda" (trbune timur ) atau berita melalui sms yang kemudian diwartakan oleh stasiun radio. Berkembangan portal berita yang independent (diluar

\footnotetext{
${ }^{3}$ Stanley J Baran \& Dennis K. Davis. Teori komunikasi massa: dasar, pergolakan dan masa depan.
} Edisi 5 (Salemba Humanika, Jakarta 2010) 
Volume 2, No. 22020

P-ISSN: 2655-5166

E-ISSN: 2715-2103

Homepage : http://journal.iaimsinjai.ac.id/indeks.php/retorika

struktur media konvensional besar) seperti portal berita RakyatSulsel, Portal Makassar. Dll serta portal berita yang menggunakan aplikasi media sosial seperti Info Makassar, Daeng info, Makassar terkini dan sebagainya, merupakan bentuk bagaimana masyarakat menggunakan ruang virtual sebagai media dalam aktifitas penyampaian informasi atau berita. Tentunya, dalam perkembangan mutakhir citizen journalism begitu fenomenal namun menimbulkan berbagai permasalahan terkait dengan akurasi berita hingga standar struktur berita yang professional. yang menjadi diskusi dalam tulisan ini adalah melakukan eksplorasi terhadap fenomena “jurnalisme warga dalam dimensi berita dan profesionalisme” tersebut.

\section{Metode Penelitian}

Penelitian ini menggunakan metode kualitatif. Data diperoleh dengan menggunakan studi literatur yang semuanya ditujukan untuk mengungkapkan gambaran terhadap fenomena sosial yang terjadi. Studi pustaka atau literatur dilakukan dengan mengkaji buku-buku dan hasil penelitian yang secara khusus mengangkat tentang konsep dan memperlihatkan penerapan citizen journalism: Fakta dan profesionalitas di era digital.

\section{Hasil dan Pembahasan}

\section{Citizen Journalism (jurnalisme warga)}

Ada banyak istilah jika mengacu pada citizen journalism seperti civic journalism, participatory journalism atau public journalism. Namun istilih citizen journalism lebih sering digunakan ketika OhmyNews menggunakan kata itu sejak 2000 an. Citizen journalism dimaksudkan sebagai kegiatan warga biasa yang bukan yang bukan wartawan professional mengumpulkan fakta dilapangan atas sebuah peristiwa, menyusun, menulis, dan melaporkan hasil tulisannya di media sosial. ${ }^{4}$ Lebih lanjut pepi Nugraha menguraikan beberapa unsur-unsur dari citizen journalism yakni: warga biasa, bukan wartawan professional, terkait fakta atau peristiwa yangterjadi, memiliki kepekaan atas fakta atau peristiwa yang terjadi itu,

\footnotetext{
${ }^{4}$ Pepi Nugraha. Citizen journalism: pandangan, pemahaman dan pengalaman. Cet.I (Kompas penerbit buku, 2012)
} 
Volume 2, No. 22020

P-ISSN: 2655-5166

E-ISSN: 2715-2103

Homepage : http://journal.iaimsinjai.ac.id/indeks.php/retorika

memiliki peralatan teknologi informasi, memiliki keingintahuan yang tinggi, memiliki kemampuan menulis atau melaporkan, memiliki semangat berbagi informasi dengan yang lainnya, memiliki blog pribadi atau blog sosial, media sosial dan akrab dengan dunia onlin, menayangkan hasil liputannya di media online seperti blog atau media sosial dan tidak berharap imbalan atas apa yang ditulisnya ${ }^{5}$

Menurut Sabjan Bodio dalam Kusnadi dan M Priono ${ }^{6}$ Secara sederhana, citizen journalism (citizen reporter) dapat diartikan sebagai jurnalisme publik, jurnalisme warga, atau jurnalisme akar rumput. Prinsip dasar citizen journalism adalah [1] pewarta (reporternya) adalah pembaca, khalayak ramai, siapapun yang mempunyai informasi atas sesuatu, [2] siapa pun dapat memberikan komentar, koreksi, klarifikasi atas berita yang diterbitkan, [3] biasanya non-profit oriented, [4] masih didominasi oleh media-media online, [5] memiliki komunitas-komunitas yang sering melakukan gathering, [6] walaupun ada kritik, tidak ada persaingan antarpenulis (reporter), [7] tidak membedakan pewarta profesional atau amatir, [8] tidak ada seleksi ketat terhadap berita-beritanya, [9] ada yang dikelola secara profesional ada pula yang dikelola secara amatir, dan [10] pembaca dapat langsung berinteraksi dengan penulisnya melalui kotak komentar atau $e$-mail.

Berdasarkan konsep pemahaman tentang jurnalisme warga (citizen journalism) diatas, kemudian dapat ditafsirkan bahwa laporan yng dibuat seseorang (bukan wartawan) merupakan sebagai respon terhadap perkembangan teknologi informasi seperti telephon (handphone) yang kemudian terakumulasi dalam perkembangan internet. Akses internet yang begitu murah serta fitur yang memungkin kita membuat halaman (blog,situs dsb) memungkinkan masyarakat dapat membuat informasi, berita dan sebagainya tanpa mesti menjadi bagian dari

\footnotetext{
${ }^{5}$ Pepi Nugraha. Citizen journalism: pandangan, pemahaman dan pengalaman. Cet.I (Kompas penerbit buku, 2012) hal 19-20

6 Kusnadi \& m. Priono. Jurnal dengan judul Citizen Journalism Indonesia: Suatu Wujud Dari Demokratisasi di Indonesia. Di akses di http://repository.ut.ac.id/2306/ pada tanggal 30 April 2021
} 
Volume 2, No. 22020

P-ISSN: 2655-5166

E-ISSN: 2715-2103

Homepage : http://journal.iaimsinjai.ac.id/indeks.php/retorika

perusahaan media legal (wartawan). Menurut Aceng Abdullah dalam Bajari ${ }^{7}$ terkait dengan fenomena jurnalisme warga, setidaknya ada beberapa hal yang melatar belakanginya;

a. Berbagai informasi yang dibutuhkan khlayak tidak selalu terpenuhi oleh media massa

b. Khalayak bukan hanya butuh informasi tapi juga butuh menginformasikan fakta dan opininya

c. Khalayak memiliki foto atau rekaman gambar yang jauh lebih baik ketimbang yang dimeliki oleh media massa umum.

Aceng Abdullah dalam Bajari ${ }^{8}$ Intensitas pengguna internet yang makin massif dan meningkatnya kesadaran/melek media serta semakin kritisnya masyarakat memungkinkan untuk mencari medium baru sebagai perwujudan untuk mengaktualisasikan atau meyampaikan suatu berita, opini dan fakta alternative yang berbeda dari media mainstream lainnya (media legal). Fenomena jurnalisme warga ini dalam internet tidak hanya semata bersifat individual atau teruarai (terstruktur), ada beberapa komunitas jurnalisme warga yang diorganisir seperti misalnya ohmynews yang didirikan oleh Oh Yeon Ho pada tahun 2000, dimana memilik 50.000 kontributor dari seluruh penjuru Korea Selatan yang setiap harinya memuat lebih dari 300 berita dari seluruh dunia.

Dalam konteks Indonesia, fenomena jurnalisme warga masih bersifat fragmentaris, jika pun ada seperti vivanews, tempo interaktif, kompas.com dsb. Adalah media online yang dikelolah lembaga media yang legal, disamping itu pula toh jika ada kolom untuk jurnalisme warga yang ditawarkan oleh media cetak konvesional (misalnya tribun timur) tak lebih dari sekedar strategi pemasaran, serta dalam kontennya masih bersifat selektif (melalui editing sesuai standard jurnalisme) atau ketakutan menurunnya tiras diakibatkan peralihan masyarakat ke internet

${ }^{7}$ Bajari, Atwar \& Saragih, Sahala Tua. Komunikasi Kontekstual; teori dan praktek komunikasi kontemporer. Rosda. Bandung 2011

${ }^{8}$ Bajari, Atwar \& Saragih, Sahala Tua. Komunikasi Kontekstual; teori dan praktek komunikasi kontemporer. Hal 34 
Volume 2, No. 22020

P-ISSN: 2655-5166

E-ISSN: 2715-2103

Homepage : http://journal.iaimsinjai.ac.id/indeks.php/retorika

dalam memperoleh data. Permasalahan yang muncul kemudian yang juga menjadi perdebatan terkait dengan jurnalisme warga adalah; akurasi berita (kebenaran), akurasi dari berita dan "profesionalisme" pemberi berita tersebut.

\section{Fakta Dan Kebenaran Berita}

Perdebatan yang terkait fakta dan kebenaran dari berita itu dapat diukur dengan sejauh mana nilai berita tersebut dapat verifikasi kelapangan, jika tidak ada maka berita tersebut adalah bohong. Dengan kata lain Ukuran sifat faktualnya dari suatu berita yakni kejadian pada realitasnya. Sedangkan jika merujuk pada kebenaran. Ini terkait bagaimana fakta itu diberitakan. Pada aspek ini tolak ukurnya masih diperdebatkan, meskipun standar dari etika jurnalisme mengisyaraktkan bahwa harus bersifat seimbang dan objektif. Aspek ini agak sulit menemukan variable empirisnya. Asumsi ini dikarenakan terkait dengan interpretasi atau bagaimana fakta-fakta disusun menjadi suatu informasi/berita. Fakta-fakta bersifat tercerai berai atau tidak utuh, dalam ranah rasionalitasnya manusia mengkonstruk sehingga menjadi pengetahuan yang utuh atau dalam istilah komunikasi menjadi informasi.

Jika berita Charnley dalam amir (dalam Fazri) merupakan laporan tercepat dari suatu peristiwa atau kejadian yangsebenarnya, penting dan menarik bagi pembaca serta menyentuh kepentingan mereka. Suatu fakta dapa dikatakan berita, apabila memenuhi syarat antara lain di publikasi oleh seseorang atau institusi yang jelas identitasnya, alamat dan penanggung jawabnya ${ }^{9}$. Suatu berita terkait dengan kejadian yang sesungguhnya dikonstruksi berdasarkan fakultas-fakultas yang dimilik seorang wartawan, sehingga antara fakta dengan berita/informasi yang disampaikan bersifat berjarak. Berger dan Luckmann dalam Bungin ${ }^{10}$ menjelaskan dengan realitas dengan memisahkan pemahaman antara "kenyataan" dan "pengetahuan", realitas menurutnya diartikan sebagai kualitas yang terdapat di

\footnotetext{
${ }^{9}$ AnharFazri dalam jurnalnya citizen journalism: kelayakan berita ditinjau dari segi bahasa dan etika jurnalistik. Diakses di http://jurnal.utu.ac.id/jsource/article/view/612 pada tanggal 30 April 2021

${ }^{10}$. Prof. dr. H.Muh. Burhan Bungin. Sosiologi Komunikasi Cet 7 (PrenadaMedia Group. Jakarta 2014
} 
Volume 2, No. 22020

P-ISSN: 2655-5166

E-ISSN: 2715-2103

Homepage : http://journal.iaimsinjai.ac.id/indeks.php/retorika

dalam realitas-realitas yang keberadaanya tidak bergantung kepada kehendak kita sendiri. Sedangkan pengetahuan didefinisikan sebagai kepastian bahwa realitasrealitas itu nyata (real) dan memiliki karakteristik yang spesifik. Demikian halnya dengan penjelasannya McQuail bahwa gambaran realitas yang diberikan di berita adalah konstruksi selektif yang dibuat dari bagian-bagian informasi yang nyata dan pengamatan yang disatukan dan diberikan makna melalui kerangka, sudut pandang, atau perspektif tertentu. Konstruksi sosial merujuk pada proses di mana peristiwa, orang, nilai dan ide pertama-tama dibentuk atau ditafsirkan dengan cara tertentu dan prioritas, terutama oleh media massa, membawa pada konstruksi (pribadi) atas gambaran besar realitas ${ }^{11}$

Menurut Eriyanto $^{12}$ (2002) dua paradigma yang menjadi mainstream terkait denga fakta/peristiwa tersebut yang pertama: aliran positivistic dimana menekankan bahwa fakta adalah seuatu yang "riil" dan besifat eksternal sebelum wartawan datang. Sementara pandangan yang kedua (konstruksivionisme) berargumentasi bahwa fakta dan realitas bukanlah sesuatu yang tinggal ambil, ada dan menjadi bahan berita. Fakta dan realitas pada dasarnya dikonstruksi. Manusia membentuk dunia merek sendiri. Takaran yang menjadi standar berita menurut kode etik juga adalah berimbang, namun upaya ini agak sulit diterapkan karena bagaimanpun juga ada kecenderung proporsi yang lebih dari salah satu pihak yang diberitakan seperti demonstrasi buruh dimana media cetak cenderung melihat dari ukuran kontribusinya pada ekonomi/pengusaha.

Dengan demikian fakta, kejadian, atau persitiwa yang kemudian diolah disebarkan yang menjadi berita, tentunya mengandung unsur-unsur subjektifitas dimana peran wartawan, redaktur pemilik menentukan bagimana fakta itu semestinya dikemas menjadi berita. Maka terkait dengan berita yang diinformasikan oleh para jurnalis warga (citizen journalism), aspek yang kemudian menjadi tolak

\footnotetext{
${ }^{11}$ McQuail, Dennis.. Teori Komunikasi Massa McQuail. Buku 1. Salemba Humanika, Jakarta. 2011

${ }^{12}$ Eriyanto. Analisis Framing. LKIS. Yogyakarta. 2002
} 
Volume 2, No. 22020

P-ISSN: 2655-5166

E-ISSN: 2715-2103

Homepage : http://journal.iaimsinjai.ac.id/indeks.php/retorika

ukur terkait substansi beritanya adalah "kebenaran" dari isi berita tersebut atau apakah berita yang disampaikan memang benar terjadi (sesuai kenyataan) terlepas bagaimana dia atau para jurnalis warga mengkonstrusi fakta-fakta itu menjadi berita.

Demikian halnya dengan berita yang disampaikan oleh aktifitas citizen jurnalisme memiliki unsur-unsur subjektifitas dari pemberitaan tersebut. Namun aspek yang tak boleh dikesampingkan oleh wartwan dan tentunya penggiat aktifitas citizen journalism adalah bagaimana struktur berita mengandung unsur-unsur yang memungkinkan para pembaca memahami dan mengetahui berita yang disampaikan. Standard berita yang mesti diperhatikan yakni bagimana berita memuliki unsur $5 \mathrm{~W}$ $=1 \mathrm{H}$ yang meliputi: what (apa yang terjadi?), who (siapa yang terlibat?), When (bilamana terjadi) where (dimana terjadinya?), How (bagaimana terjadinya?) dan why (mengapa bias terjadi?) ${ }^{13}$.

Disamping itu, terlepas dari adanya unsur-unsur nilai dalam mengkotruksi peristiwa atau fakta oleh suatu media, wartawan atau citizen journalism, namun upaya untuk menekankan suatu karakter berita yang objektif mesti menjadi perhatian dan setidaknya dalam konteks Indonesia upaya pemenuhan standard berita yang objektif tercermin dalam peraturan yang menjdai standard etik para jurnalis atau yang lebih dikel dengan kode etika jurnalistik. Seperti misalnya pasal 1 pentingnya menghasilkan berita yang berimbang dan akurat; pasal 2 yang mengandung unsur pentingnya professional seorang wartawan;serta pasal 3 yakni pentinnya berita bersifat berimang, tidak mencampurkan fakta dan opini yang menghakimi, serta menerapkan asas praduga tak bersalah. ${ }^{14}$ Menurut Mcquail objektifitas adalh bentu tertentu (dan harus) dari praktik media atau citizen journalism, adapun cirinya adalah:1), penerapan posisi keterlepasan dan netralitas terhadap objek peliputat;2), adanya upaya menghindari keterlibatan, tidak berpihak

\footnotetext{
${ }^{13}$ Hikmat Kusumaningrat \& Purnama kusumaningrat. Jurnalistik; teori dan prakti Cet V( PT Remaja Rosdakarya. Bandung 2014) hal 129

${ }^{14}$ Indah Suryawati, Jurnalistik: suatu pengantar (Ghalia Indonesia, Bogor. 211)
} 
Volume 2, No. 22020

P-ISSN: 2655-5166

E-ISSN: 2715-2103

Homepage : http://journal.iaimsinjai.ac.id/indeks.php/retorika

dalam perselisihan atau menunjukan bias (seimbang)membutuhkan keterikatan yang kuat terhadap akurasi dan jenis kebenaran media lainnya ${ }^{15}$

\section{Profesionalisme; Wartawan Versus Jurnalisme Warga}

Salah satu isu yang menjadi perdebatan pula mengenai jurnalisme warga adalah profesionalitas. Meskipun, perdebatan tentang pentingnya standard jurnalisme masih mengalami perdebatan pula, sebagaimana dikatan oleh Baran \& Davis $^{16}$, bahwa standard profesionalitas seringkali abstrak dan maknanya kabur. Mereka menambahkan bahwa dibandingkan dengan bidang kedokteran atau hukum, pembentukan profesionalitas media tidak memiliki standard untuk pelatihan dan lisensi. Dalam kasus Negara Indonesia, Indicator-indikator profesionalitas wartawan misalnya terakumulasi kedalam kode etik jurnalisme sebagaimana termaktub dalam Peraturan dewan pers Nomor: 6/Peraturan-DP/V/2008 ${ }^{17}$ seperti: Wartawan Indonesia menhormati hak masyarakat untuk memperoleh informasi yang benar ; Wartawan Indonesia menempuh tata cara yang etis untuk memperoleh dan menyiarkan informasi serta memberikan identitas kepada sumber informasi; Wartawan Indonesia menghormati asas praduga tak bersalah, tidak mencampurkan fakta dengan opini, berimbang dan selalu meneliti kebenaran informasi, serta tidak melakukan plagiat; Wartawan Indonesia tidak menyiarkan informasi yang bersifat dusta, fitnah, sadis dan cabul, serta tidak menyebut identitas korban kejahatan susila dan seterusnya .

Konsep kode etik tersebut merupakan batasan yang mesti menjadi pertimbangan bagi wartawan, tidak terlalu sulit mengaplikasinya meskipun agak susah ditemukan pada realitasnya, Karena adanya factor-faktor kepentingan, pemilik, editor ataupun ideology suatu Negara yang terkadang menjegal /menghambat wartawan "idealis" tersebut. Pencapaian profesionalitas pada

${ }^{15}$ McQuail, Dennis.. Teori Komunikasi Massa McQuail. Buku 1. Salemba Humanika, Jakarta. 2011. Hal 222

${ }^{16}$ Stanley J Baran \& Dennis K. Davis. Teori komunikasi massa: dasar, pergolakan dan masa depan. Edisi 5 (Salemba Humanika, Jakarta 2010) hal 141

${ }^{17}$ Peraturan dewan pers Nomor: 6/Peraturan-DP/V/2008 merupakan pengesahan surat keputusan dewan pers nomor 03/sk-dp/iii/2006 tentang kode etik jurnalistik sebagai peraturan dewan pers 
Volume 2, No. 22020

P-ISSN: 2655-5166

E-ISSN: 2715-2103

Homepage : http://journal.iaimsinjai.ac.id/indeks.php/retorika

wartawan legal umumnya melalui pelatihan-pelatihan atau training kewartawanan sebulum dan ketika dia diterima dalam suatu perusahaan media. Ini berbeda dengan jurnalisme warga, dimana tidak pernah mengenyam pendidikan kerjurnalisan. Namun etika sebagimana dijabarkan diatas tidaklah mustahil bias juga diterapkan oleh jurnalisme warga. yang menjadi nilai lebih dari wartawan formal adalah dengan sokongan dana dari perusahaannya, memungkinkan untuk mengeksplor informasi lebih dalam, ini agak sulit berlaku bagi jurnalis warga. dengan kata berita yang diinformasikan oleh jurnalis warga tidaklah mendalam meskipun tidak mustahil itu dicapai. Perbedaan terkait pencarian informasi ini sebenarnya nilai lebih dari wartwan legal apatah lagi menurut Baran \& Davis ${ }^{18}$ jurnalisme warga atau citizen journalism (misalnya Blogger)

"(meskipun)kebanyakan dari mereka tidak berpura-pura melakukan pencarian berita yang asli,(namun) merekabergantung pada para jurnalis untuk melakukan hal tersebut. Merkea terlibat dalam diskusi dan gossip mengenai peristiwa-peristiwa bersumber dari internet. Mereka meberi nilai tambah kepada berita...

Salah satu isu lain yang menjadi persoalan terkait tanggung jawab, berita yang disampaikan oleh warga melalui sms kemungkinan bersifat sesat, namun pada ranah internet, persoalan ini dapat diantisipasi dengan melacak alam pembuat blog, portal berita hingga media sosial tersebut. Profesionalisme seorang penggiat dalam berita baik wartawan (yang wajib dimiliki) maupun citizen journalism (yang seharusnya memiliki) tercermin dalam berbagai karakter dan prilaku yang senantiasa dalam koridor nila-nilai kode etik jurnalistik. Karakter ini menurut Haris Sumadiria, tercermin dalam berbagai bentuk yakni; ksatria dalam mengemban profesi (beratnggung jawab, membela kebanaran dan keadilan memiliki integritas), bertanggung jawab dan bijaksana, tidak menyesatkan masyarakat (berita akurat,

${ }^{18}$ Stanley J Baran \& Dennis K. Davis. Teori komunikasi massa: dasar, pergolakan dan masa depan. Edisi 5 (Salemba Humanika, Jakarta 2010) 
Volume 2, No. 22020

P-ISSN: 2655-5166

E-ISSN: 2715-2103

Homepage : http://journal.iaimsinjai.ac.id/indeks.php/retorika

jelas dan terstruktur), tidak menerima imbalan dari berita dan menghormati hak masyarakat ${ }^{19}$.

Dalam perkembangannya, citizen journalism sebagaimana disimpulkan oleh Aryo Subarkah, Faruk HT dan Budi Irawanto bahwa jurnalisme warga atau citizen journalism telah menerapkan standar-standar jurnalisme professional (dan ini juga diakui dan dibesarkan oleh jurnalisme professional $)^{20}$. Namun prinsip-prinsip profesionalisme yang juga diterapkan oleh jurnalisme warga (citizen journalism), namun jika menurut Abdullah dalam Bajari ${ }^{21}$ wartawan legal adalah jurnalis yang tercatat dan terikat oleh organisasi media, pihak media bias meminta penjelasan atau pertanggung jawaban apabila beritanya bermasalah. Sedangkan citizen journalism, menurut Aryo Subarkah, Faruk HT dan Budi Irawanto bahwa posisi jurnalisme warga (citizen journalism) tidaklah sebaik jurnalisme "professional" yang keberadaannya telah diakui oleh Undang-undang Pers. Jurnalisme warga bukanlah pers, jika terjadi masalah Hukum karena kontent merugikan dan melanggar UU ITE maka akan di perkarakan dan dipenjara ${ }^{22}$, dan ini akan berbeda jika jurnalisme professional jika tersandung hukum, maka dewan pers akan melakukan mediasi sebelumnya.

\section{Kesimpulan}

Sebagaimana dikatakatan oleh Jeff Jarvis dalam Baraan\&Davis" 23 "kita semua adalah jurnalis satu-satunya hal yang membuat jurnalis adalah seorang jurnalis sebelum kemunculan blog adalah akses kepada mereka yang memiliki media. Fenomena jurnalis warga adalah suatu keniscayaan terkait dengan semakin

${ }^{19}$ Drs. A.S. Haris Sumadiria. Hukum dan Etika media Massa. PT. Remaja Rosdakarya. Bandung 2019. Hal 219-223

20 Aryo Subarkah, Faruk HT dan Budi Irawanto. Menyoroti Jurnalisme warga: lintasan sejarah, konflik kepentingan, dan keterkaitannya dengan jurnalisme profeional. Jurnal Vol 03 nomer 1 Tahun 2019. Diakses di http://jurnal.unpad.ac.id/kajian-jurnalisme/article/view/21762 pada tanggal 30 April 2021

21 Bajari, Atwar \& Saragih, Sahala Tua. Komunikasi Kontekstual; teori dan praktek komunikasi kontemporer. Rosda. Bandung 2011

22 Aryo Subarkah, Faruk HT dan Budi Irawanto....hal 15 bagian kesimpulan

${ }^{23}$ Stanley J Baran \& Dennis K. Davis. Teori komunikasi massa: dasar, pergolakan dan masa depan. Edisi 5 (Salemba Humanika, Jakarta 2010) 
Volume 2, No. 22020

P-ISSN: 2655-5166

E-ISSN: 2715-2103

Homepage : http://journal.iaimsinjai.ac.id/indeks.php/retorika

intensnya dan massifnya penggunaan teknologi komunikasi terutama internet. Jurnalisme warga merupakan upaya aktualisasi diri masyarakat untuk terlibat dalam dunia informasi (pertukaran informasi) atau berpartisipasi dalam dunia jurnalisme yaitu dunia dalam menyebarkan informasi melalu platform media yang dimiliki baik berupa blog atau media sosial lainnya. Citizen Jounalisme sering menyajikan beritaberita yang tersentuh atau dimuat oleh media profesional, dan inilah menjadi sisi kelebihan dari citizen journalism.

Dalam proses pembuatan berita, wartawan profesionalisme atau jurnalisme warga "citizen journalism" tentunya semakin seimbang dalam menerapkan teknik dan prinsip pembuatan berita sesuai dengan standar penulisan berita dan senantiasa mempertimbangkan standard etik, nilai-nilai atau moral dalam pemberitaan. Tentunya dalam proses pengelolan suatu peristiwa atau fakta untuk menjadi berita tentunya berbeda, hal ini dikarenakan nilai-nilai atau perspektif yang mempengaruhi cara wartawan atau citizen journalism dalam memandang dan mengkonstruksi berita. Namun seiring dengan proses interaksi dan kerja sama dengan jurnalisme professional, citizen journalism semakin lama menunjukkan suatu prinsip kerja yang professional, meskpin dalam konteks keberadaan tidak diakui secara hukum.

\section{Daftar Pustaka}

Aryo Subarkah, Faruk HT dan Budi Irawanto. Menyoroti Jurnalisme warga: lintasan sejarah, konflik kepentingan, dan keterkaitannya dengan jurnalisme profeional. Jurnal Vol 03 nomer 1 Tahun 2019. Diakses di http://jurnal.unpad.ac.id/kajian-jurnalisme/article/view/21762 pada tanggal 30 April 2021

Bajari, Atwar \& Saragih, Sahala Tua. 2011. Komunikasi Kontekstual; teori dan praktek komunikasi kontemporer. Rosda. Bandung.

Baran, Stanley j \& Davis Dennis K. 2010. Teori Komunikasi Massa. Salemba Humanika. Jakarta.

Briggs, Asa \& Burke, Peter. 2006. Sejarah Sosial Media. Yayasan obor. Jakarta Bottomore, T.B. 2006. Elit dan Masyarakat. Akbar Tandjung Institue.

Bungin, Prof. Dr. H.M. 2014. Sosiologi Komunikasi. Kencana Prenada media grup. Jakarta. 
Volume 2, No. 22020

P-ISSN: 2655-5166

E-ISSN: 2715-2103

Homepage : http://journal.iaimsinjai.ac.id/indeks.php/retorika

Eriyanto. 2002. Analisis Framing. LKIS. Yogyakarta.

Fazri, Anhar dalam jurnalnya citizen journalism: kelayakan berita ditinjau dari segi bahasa dan etika jurnalistik. Diakses di http://jurnal.utu.ac.id/jsource/article/view/612 pada tanggal 30 April 2021

Fachruddin, Andi. 2019. Journalism Today.Prenadamedia group. Jakarta

KusumaNingrat, Hikmat \& Kusumaningrat, Purnama. 2014. Jurnalistik:Teori dan Praktik. PT REMAJA ROSDAKARYA. Bandung

Kusnadi \& m. Priono. Jurnal . Citizen Journalism Indonesia: Suatu Wujud Dari Demokratisasi di Indonesia. Di akses di http://repository.ut.ac.id/2306/ pada tanggal 30 April 2021

McQuail. 2011. Teori Komunikas Massa McQuail. Buku 1 Penerjemah. Putri IvaIzzati. Penerbit Salemba Humanika. Jakarta.

Nugraha, Pepih. 2012. Citizen Journalism: pandangan, Pemahaman dan pengalaman. Penerbit Buku Kompas. Jakarta

Sumadiria, Drs. A.S. Haris.2019. Hukum dan Etika Media Massa: Panduan Pers, penyiaran dan media siber. PT. RemajaRosdakarya. Bandung 